\title{
REAGANOMICS: THE REVOLUTION IN AMERICAN POLITICAL ECONOMY
}

\author{
Charles E. Jacob*
}

I

INTRODUCTION

The first year of the Reagan Administration produced a set of changes in political-economic relationships so novel as to merit the denomination "revolutionary." The sobriquet, Reaganomics, is used in this article's title on purpose to emphasize the importance of President Reagan's personal role in engineering great change. Although the reorientation of the tax structure constitutes the centerpiece of Reaganomics, it must be noted that the economic package also includes reductions in domestic programs, bureaucracies, and support. Moreover, another aspect of the Reagan Administration's revolutionary reallocation of state values has taken the form of nonincremental increases in defense spending.

Evidence of revolution may be found in authoritative policy enactments which document historic change. On February 5, 1981, President Reagan spoke to the nation from the Oval Office and called for a reduction in personal taxes of $30 \%$ over a three-year period. In addition, speaking further to the supply-side ethos, the President proposed accelerated depreciation rewards to business to encourage investment and growth. ${ }^{1}$ On February 18, the President submitted the details of his tax cut plan along with proposed budgetary reductions of $\$ 49$ billion in domestic program spending in a special "white paper" which constituted the Administration's revision of the Carter Economic Report of 1981.2

On July 26, 1981, Congress adopted an omnibus reconciliation measure (popularly titled the Gramm-Latta proposal) which trimmed $\$ 38.2$ billion from spending authority previously apportioned among some eighty-three domestic programs. ${ }^{3}$ On July 29, 1981, the House of Representatives accepted the Senate's version of what would become the Economic Recovery Tax Act of 1981,4 which reduced individual tax rates by $25 \%$ over the succeeding thirty-three months. Moreover, the measure contained a

Copyright $\odot 1985$ by Law and Contemporary Problems

- Professor of Political Science, Rutgers University, New Brunswick, New Jersey.

1. See Address to the Nation on the Economy, 1981 Pub. Papers 79, 82 (Feb. 5, 1981).

2. White House Report on the Program for Economic Recovery, 1981 Pub. PAPERS 116-32

(Feb. 18, 1981); see Address Before a Joint Session of Congress on the Program for Economic Recovery, 1981 Pub. Papers 108 (Feb. 18, 1981).

3. See Tate \& Plattner, House Ratifies Savings Plan in Stunning Reagan Victory, 39 Cong. Q. WeEkLY REP. 1127 (1981).

4. Pub. L. No. 97-34, 95 Stat. 172. 
provision for future implementation of the indexing of taxes to counter the impact of inflation on tax bracket escalation, and a multitude of provisions which afforded tax breaks to encourage the supply side to invest, to expand, and to profit. ${ }^{5}$

While the above acts of Congress may be regarded as indicators of revolutionary change, the nature and qualities of that change are what constitute the substantive revolutionary aspect. When the term "revolutionary" is used in the contemporary, benign, democratic sense, one usually thinks first of scope. 'That is, the term is reserved for large, sweeping, or fundamental alterations in some aspect of the existing order of things. Students of policymaking have often noted that such changes are accompanied by and based upon relatively little knowledge, both theoretical and empirical. For many policy analysts, normal decisionmaking is incremental (methodical modifications at the margins of an existing corpus of policy). ${ }^{6}$ Less frequently do decisionmakers forego caution and boldly strike out in new directions. Such revolutionary dispositions may be motivated by crisis, ideological zeal, or as some theorists have suggested, "grand oppportunities."7 Elements of each of these can be seen in Ronald Reagan's fervid adoption of the preachments of supply-side theory as a prescription for the restoration of an ideal America of his personal vision. No matter that supply-side theory lacked the imprimatur of the professional economics community; neither theoretical nor empirical consensus characterized that discipline in any case. ${ }^{8}$ A historical parallel in point is the Roosevelt Revolution which charted the course of American history for a half-century and was similarly flexible in its intellectual underpinnings.

Another quality which characterizes modern revolutionary thrusts is pace. Sweeping changes are not only made, but made in a whirlwind of seemingly frenzied activity. The new Administration in this instance reprogrammed the national policy agenda in a matter of three months; issuing its own economic report as well as a 400-page statement of budget revisions for fiscal 1982.9 The elements of perceived crisis which influenced these moves can be summed up in a few numbers printed in President Carter's last economic report: the gross national product was in absolute decline $(-0.3 \%)$; unemployment stood at $7.1 \%$; and most nettlesome, inflation was marked by a $13.5 \%$ rise in the consumer price index in $1980 .{ }^{10}$ (1981)

5. Fessler, Reagan Economic Plan Nears Enactment, 39 Cong. Q. WEeKLY ReP. 1371, 1375-76

6. See A. Wildavsky, The Politics of the Budgetary Process 15 (3d ed. 1979); Lindblom, The Science of "Muddling Through," 19 PUB. AD. REv. 79 (1959); Lindblom, Decision-Making in Taxation and Expenditures, in Public Finances: Needs, Sources, and Utilization 295-336 (1961).

7. D. Braybrooke \& C. Lindblom, A Strategy of Decision 68 (1963).

8. See L. Thurow, Dangerous Currents: The State of Economics (1983).

9. See White House Report on the Program for Economic Recovery, supra note 2; Executrve Office of the President, Office of Management and Budget, Fiscal Year 1982 Budget Revisions: Additional Details on Budget Savings (1981) (PrEx 2.8/7:982).

10. See Economic Report of the President 138, 293, 316 (1981) (Pr 39.9:981). 
Finally, the Reagan policy coup fulfilled another of the theoretical expectations for policy revolution: it started at the top and was consummated at the highest levels. Professors Braybrooke and Lindblom observed that

[ $t$ ]he political locus for decisions of this kind lies in the deliberations of policymakers and their advisers at the highest level . . . [T]ypically, the decision effecting large change is not made at the lower levels of government, nor, specifically, is it made in the middle or lower ranks of the administrative service. ${ }^{11}$

The central purpose of the present inquiry is not to define policy revolution but to explain its occurence in the Reagan case. Such an analysis takes an essentially political form rather than an economic one. We are interested in exploring how political resources can be applied to the governmental process to achieve massive (in this case, economic) policy change. For purposes of analysis, three defining perspectives will be posed. The first perspective has its site mainly in the executive domain and looks to questions of policy formulation, planning, and the management of people and processes involved in these activities. Thus, this perspective is concerned with the process of setting the policy agenda. The second perspective focuses on the process of the adoption of policy and thus the environment shifts to the legislative arena. Here phenomena of conflict and bargaining, both within the institution and between legislative and executive actors, mark political activity. Finally, departing from institutional perspectives, a category of analysis which is defined by the policy environment and the role of personal, presidential leadership within it, is examined. A rather protracted footnote to the considerations raised by these three perspectives will look to a second stage of the policy innovation process. Thus-and to extend the metaphor of revolution backward to its historical roots-note will be made of the Thermidorean reaction to the shock of revolution. The official legislative reaction of 1982 is of course the Tax Equity and Fiscal Responsibility Act. ${ }^{12}$

II

Setting the Agenda

\section{A. World View}

To understand the making of the revolution of 1981, one must begin with Ronald Reagan himself. The process of policy formulation is so complex, so disjointed, so subject to delays and the claims of institutionalized veto groups, that only a committed and determined manager can hope to force the system to realize his broad goals. It was that commitment and zeal for achievement of a general policy consequence in tune with the President's world view that held the system together, at least for a crucial time. ${ }^{13}$ The idea of world view conveys an important distinction about the role of basic values in motivating

11. D. BRAYbrooke \& C. LindBlom, supra note 7, at 68-69.

12. Pub. L. No. 97-248, 96 Stat. 324 (1982).

13. "World view" alludes to J.D. Barber's characterization of those "primary, politically relevant beliefs, particularly his conception of social causality, human nature, and the central moral conflicts of the time." J. Barber, The Presidential Character 7-8 (1977). 
and reinforcing policy choice. The more familiar term, ideology, suggests-at least in its historic European origins-a greater measure of intellectual depth and philosophical coherence than characterizes the outlook of most American presidents. Reagan adheres to a loosely structured personal value scheme which is grounded in a generally conservative twist applied to traditional, middle American, middle class social precepts. This melange of attitudes includes, but is not limited to, ideals of individualism, the efficacy of effort, the supremacy of private social arrangements over governmental regulation, and of private, unfettered economic enterprise. Importantly, the view assumes that social and economic rewards should be distributed in accord with the energy and effectiveness of individualistic enterprise. ${ }^{14}$

The reason Reagan has so often been characterized as an ideologue is that he has held these views long, resolutely, and publicly. His determination to oversee a policy revolution and his conviction that it would be possible is not surprising in one who believes literally in the Horatio Alger myth. When the New York Times queried Reagan about his favorite books, his response was heavily weighted in favor of the self-help, do-or-die adventure classics, from King Arthur to Frank Merriwell at Yale. In explaining his choices, Reagan admitted:

I'm a sucker for hero worship to this day . . . . All in all, as I look back I realize that all my reading has left an abiding belief in the triumph of good over evil. These were heroes who lived by the standards of morality and fair play. ${ }^{15}$

A related aspect of his outlook is an incurable optimism. All those who examine Reagan are struck by this penchant. One biographer has noted:

"Life is just one grand sweet song, so start the music," Reagan had written as a high school senior in 1928, the year before the great stock market crash. More than half a century later, this pervasive optimism was driving the economic decisions of his administration. ${ }^{16}$

Herbert Stein, a Nixon-Ford era economic adivser who participated on Reagan's Economic Policy Adivsory Board, relates with some incredulity that when he told the President that the art of economic forecasting was insufficiently developed to guarantee that inflation could be reduced without recession, the President simply brushed aside such doubts about the inevitability of his program's success. ${ }^{17}$

It is not surprising that a mind-set of this sort would find the claims of the supply-side fraternity to be a congenial policy vehicle. The essential proposition-that the appetites and energies of economic man would be enhanced by state activity which removed the hand of regulation and rewarded, through the tax system, the instinct to invest, expand and growwas beguiling. With the assistance of hypotheses offered by Arthur Laffer, a conservative University of Southern California economist, and by a drum beat

14. On the American conservative tradition, see C. Rossiter, Conservatism in America (1955).

15. N.Y. Times, Aug. 30, 1981, Book Review, § 7, at 21 , col. 1.

16. L. Cannon, Reagan 322 (1982).

17. See H. Stein, Presidential Economics: The Making of Economic Policy from Roosevelt to Reagan and Beyond 395 n.9 (1984). 
of support by Wall Street Journal economics writer, Jude Wanniski, the syllogism concluded that even a massive cut in tax rates at the upper margins would be compensated by increased tax receipts flowing from expansion and economic growth. Thus, tax reductions and balanced budgets could be achieved together. This dogma sounded distressingly like wanting it "both ways" or, as Herbert Stein described it, "the economics of joy."18

The measure of Ronald Reagan's commmitment to the general notions of Kemp-Roth was his capacity to withstand the doubts and criticisms of many of his most distinguished Republican confreres. Even during the campaign, orthodox, conservative economists and former officials such as Nixon's Council of Economic Advisers Chairman, Alan Greenspan, Nixon's Treasury Secretary, George Shultz, former Federal Reserve Chairman, Arthur Burns, and long-time academician, Milton Friedman, tried to persuade the candidate to question such acts of faith as reliance on "Laffer Curves."'19 Nevertheless, the candidate prevailed throughout the campaign and, after November 4, 1980, proceeded, as President, to transform campaign pledges into public policy.

\section{B. Machinery of Choice}

In one sense, candidate Reagan had set the public agenda even as he took the oath of office. Professor Kingdon makes the distinction between "the governmental agenda" - the list of subjects that are getting attention-and "the decision agenda" - the list of subjects within the governmental agenda that are up for an active decision. ${ }^{20}$ The first version of agenda-setting was accomplished; there remained the more daunting task of organizing active decisionmaking. The performance of that task depends largely upon the president's capacity as administrative leader and manager. To move from general dispositions toward problems to specific proposals designed to treat them is to move from individual preference to collective decisionmaking. The American presidency is amply endowed with resources for managing the policy process, chiefly personnel management, organizational controls, and personal persuasion. How effectively these resources are deployed will usually determine the degree to which the president does in fact manage the decision agenda.

Since the Employment Act of $1946^{21}$ the institutional presidency has spawned a subpresidency that might be termed an economic policymaking secretariat. The major institutional presences are now well established. The Treasury Department (DOT), of course, takes its origins with the Republic itself. The other major components are twentieth-century elaborations. The

18. Id. at 235. The supply-side canon has a substantial press and periodical base but the chief works which have gained wide public attention include G. Gilder, WealTH and PoverTy (1981), and J. Wannisky, The Way the World Works (1978).

19. See Silk, On the Supply Side, in Reagan the Man, the President (H. Smith ed. 1980).

20. See J. Kingdon, Agendas, Alternatives, and Public Policies 4 (1984).

21. 15 U.S.C. $\$ 1021$ (1976). 
Office of Management and Budget (OMB) had its beginnings as a Bureau in 1921. The Federal Reserve Board (the Fed) is a Wilsonian product, devised in 1913 to reform and regulate the banking system. The Council of Economic Advisers (CEA) came about as the administrative agent of the Employment Act's declaration of macroeconomic policy objectives. ${ }^{22}$ Thus, since 1946 , national economic planning has been legitimated and its responsibility lodged in the presidency that has the CEA as a permanent source of economic advice and judgment. ${ }^{23}$ Of course, economic advice and information flow from a host of other specialized agencies of government and various ad hoc advisory bodies that presidents establish to suit their own decisional styles. Yet, the "big four" stand out as preeminent in the councils of economic planning.

Although the OMB, CEA, and DOT meet and consult regularly to frame the periodic economic forecasts as the "Troika," it has become practice in recent years to include the Fed in these information exchanges and forecasting ventures. What is more notable, however, is that each of these institutions has specific and somewhat different functions-and therefore perspectives-even as they participate in a collective process. The Treasury, the government's bill-payer, performs a function that concentrates the attention of its secretaries wonderfully on financially cautious paths. The Director of OMB clearly feels some of the same kinds of chastening responsibilities as does the Secretary of the Treasury, but the Director has emerged in recent decades more as a special presidential agent whose obligation is to protect the president's agenda from bureaucratic intrusions and to help shape this agenda. The Fed is the historic monetarist bastion, and its independent authority over the money supply and interest rates frequently makes it an object of presidential importunity rather than White House control. Only the CEA has a purely advisory role, unencumbered by administrative responsibilities. The Council can profit by its status as a ministry of pure wisdom; it can also suffer from its status as a political actor without a political base in governing resonsibilities or political support in the form of citizen clienteles. In the end, even more than its institutional partners, the CEA is only what the president decides to make of it.

The importance of these institutions to the policy formation process is that each exercises legitimate and routine functions that affect planning and policy choice. General notions about fiscal policy may set the stage, but quarterly forecasts by the Troika, calendar-driven OMB decisions, meetings of the Open Market Committee of the Fed, and even the February issuance of the economic report are all activities which cannot be ignored. In a similar vein, Treasury reports on gold-outflow, revised consumer price and wage indices,

22. Those objectives are stated as follows: "to promote maximum employment, production, and purchasing power." Employment Act of 1946, Pub. L. No. 304, § 2, 60 Stat. 23, 23.

23. There is a substantial and growing literature investigating these institutions. Leading studies include C. Anderson, A Half Century of Federal Reserve Policy Making, 1914-1964 (1965); L. Berman, The Office of Management and Budget and the Presidency, 1921 -1979 (1979); E. Flash, Economic Advice and Presidential Leadership (1965); and L. Pierce, The Politics of Fiscal Policy Formation (1971). 
and reports of changes in private savings behavior are bits of information laden with implications which emerge routinely from the bureaucratic establishment. As such, they suggest, collectively, some limitations on presidential mastery of the decisional flow. ${ }^{24}$

A major determinant of the president's ability to utilize the bureaucratic machinery to advance his programs is his capacity to appoint the heads of the policy agencies. For most presidents, this task itself is largely delegated, and the intended linkage between people and policy success is more in the nature of guesswork than certainty. Reagan's experience attests to these truths. A Transition Advisory Committee began during the pre-election period to organize the staffing process. After the inauguration, presidential counselor Edwin Meese proceeded to create the economic secretariat. ${ }^{25}$ The results were broadly in accord with the President's conservative preferences. The difficulty that would emerge, of course, reflected the inconsistencies among components of the President's economic objectives (tax cuts, along with defense spending growth, along with balanced budgets). When William Simon, as first choice, rejected the Treasury post, the talent hunters proposed Donald Regan of Merrill-Lynch as a substitute. True believers of the supply side were not enthusiastic, since Regan was hardly one of that fraternity. In July, 1980, he had testified before the House Ways and Means Committee against the Kemp-Roth tax cut proposal. ${ }^{26}$ Nevertheless, he was found acceptable by the group and the President because he was a well-known conservative and congenial to Wall Street. ${ }^{27}$

In the case of the OMB directorship, the appointee, David Stockman, had campaigned for the job. ${ }^{28}$ Congressman Jack Kemp also lobbied for the appointment. Stockman was a longtime associate and ideological ally Congressman Kemp, and together they coauthored the campaign advire document, "Avoiding a GOP Dunkirk."29 Although Stockman would initially be identified as a hard-line supply-sider, his convictions quickly waned during the first year.

Certainly, the bastion of zealotry for supply-side theory was to be found in the second level of Treasury. The Undersecretary for Tax Policy, Norman B. Ture, had conservative University of Chicago and Wharton School credentials as well as experience in the Nixon government. The Assistant Secretary for International Economics, Paul Craig Roberts, who had been an aide to Jack

24. For a thoughtful analysis of the impact of routines, standard operating procedures, and established bureaucratic repertoires on decisionmaking, see G. Allison, ESSENCE Of DeCISION 78-95 (1971).

25. The economic secretariat is a body of economic counsellors, meeting routinely, whose work overlaps with formal institutions.

26. Gregg \& Tate, Reagan Economic Officials Put Differences Behind Them, 39 Cong. Q. WEEkLY REP. 259 (1981).

27. See L. Barrett, Gambling with History: Ronald Reagan in the White House 67 (1983).

28. See id. at 70 .

29. The text of the memorandum, "Avoiding a GOP Dunkirk," is printed as an appendix in W. Greider, The Education of David Stockman and Other Americans 199-59 (1982). See also L. CANNON, supra note 16 , at 309 . 
Kemp, joined Ture as the leading torchbearer for supply-side orthodoxy through the developing internal struggles. ${ }^{30}$

In contrast, the Council of Economic Advisers was in no sense a supplyside armory. Chairman Murray Weidenbaum was a traditional conservative economist whose reputation was based more upon his seminal work on regulation and its economic costs than on macroeconomic theory. Adviser Jerry Jordan was the monetarist presence on the CEA and Adviser William Niskanen, Jr., an old Reagan hand, saw some merit in the supply-side argument but was too much an intellectual renegade to conform to any particular economic dogma. ${ }^{31}$ Needless to say, Fed Chairman Paul Volcker was an independent presence, immune from direct presidential control.

\section{Managerial Style}

Most of the time, presidential-level officials do not offer their advice in one-on-one situations. The idiosyncratic organizational stamp which a president places upon his policy system can have portentous consequences for outcomes. The chief characteristic of Reagan's management style is a long established belief in maximum delegation. He sees executive responsibility as that of setting broad objectives and depending heavily on subordinates to fashion the means for their achievement. Inevitably, this belief would lead (as was the case with his recent predecessors) to substantial dependence upon his White House chief secretariat, composed of Edwin Meese, James Baker, and Michael Deaver. ${ }^{32}$ Consistent with these notions was Reagan's wish to fashion a personal version of cabinet government. Early on in his Administration, he created six cabinet councils designed to filter policy planning through broader functional units. ${ }^{33}$ The Economic Policy Council was chaired by Secretary Regan and included Stockman and Wiedenbaum as well as Commerce Secretary Malcolm Baldridge and Trade Representative John Block. The first job of this council was to build and articulate an Administration consensus in favor of Reaganomics. Secretary Regan, earlier apostate, cast away all doubts and called for the President's tax program at once, arguing that it "cannot wait until budget outlays are reduced." Others of the economic policy elite quickly concurred. ${ }^{34}$

The early consensus would, however, be short-lived. The bad news of deficit recalculations suggested that it was unrealistic to expect the magic of supply-side theory to work. Voices within the Administration began arguing for a smaller tax cut, delays in the implementation of the cuts and/or even a scaling back of the massive defense budgetary increases. OMB Director

30. See R. Brownstein \& N. Easton, Reagan's Ruling Class 12 (1982); see also P. Roberts, The Supply Side Revolution (1984).

31. See R. Brownstein \& N. Easton, supra note 30, at 70-74.

32. See L. BARRETT, supra note 27, at 80-106 for a good description. Cannon's summary of Reagan's philosophy gives the title to chapter 22 of his biography: "The Delegated Presidency," supra note 16, at $971-401$.

33. N.Y. Times, Feb. 15, 1981, $\$ 1$, at 1 , col. 1 .

34. Gregg \& Tate, supra note 26 , at 259. 
Stockman took the lead in an attempt to bring about a recalibration of Reagan's policy timetable. This fallen supply-sider now engaged in a series of strategies to cut Defense Secretary Casper Weinberger's budget, give aid and comfort to congressional critics and Republican supply-side skeptics, and maneuver the President into a position of compromising on the tax cut. The deviousness of the Stockman "subversion" and the measure of his own disillusionment with the early hopes would later be embarrassingly publicized in the famous Atlantic Monthly article based upon a year's candid interviews that the Director had given to a Washington Post journalist. Let one quotation suffice:

Some of the naive supply-siders just missed this whole dimension . . . . You don't stop inflation without some kind of dislocation . . . . The supply-siders have gone too far. They created this nonpolitical view of the economy, where you are going to have big changes and abrupt turns, and their happy vision of this world of growth and no inflation with no pain....

Whenever there are great strains or changes in the economic system, . . . it tends to generate crackpot theories, which then find their way into legislative channels. ${ }^{35}$

For the most part, Stockman's views were shared by the White House staffers who were especially sensitive to the political consequences of deficits and unemployment. The supply-siders within the Administration fought back with the usual bureaucratic weapons of memorandums and press leaks, and Craig Roberts' ongoing journalistic advocacy in the Wall Street Journal. ${ }^{36}$ The press, of course, was indulgent of the fresh copy it received periodically concerning internal administrative conflict.

In retrospect, it seems almost surprising that the combination of internal pressures on the President from his own lieutenants in favor of reformulation and the skepticism of part of his own congressional leadership about Reaganomics did not delay the presidential economic agenda far more than it did. The President's loose managerial style and easy tolerance of discord among his subordinates made agenda control tenuous at times. The explanation for the President's first triumph surely lies in his personal determination based upon the conviction, however misguided, that his tax program amounted to a heroic achievement on the road to an ideal America. Moreover, his ability to retain the apparent allegiance of a majority of Americans was politically instrumental in overcoming the divided counsels of his own government. This lesson would be repeated at the next stage of the policy process.

\section{III}

\section{Pushing the Agenda Through Congress}

Although agenda-setting and legislative bargaining are used as different analytical constructs, of course the activities and time periods during which they predominate overlap. Thus, in the case of Reagan's economic policy

35. Greider, The Education of David Slockman, ATL. MontHLy 27, 54 (Dec. 1981).

36. See P. Roberts, supra note 30 , at $108,117-18,141$. 
initiative, while formulation activities involved intra-executive negotiations and legislative activities involved interbranch relationships, each of these processes conditioned the other at various points. For example, the initial presentation of the tax program to Congress incorporated compromises in the President's earlier intentions in order to anticipate congressional opposition. These minor compromises were brought about as a result of the persuasiveness of the President's advisors. Thus, in the opening legislative gambit, indexing of tax brackets was delayed until July 1, rather than taking effect January 1, the goal of balancing the budget (given the program's revised cost calculations) was moved back to 1984 from the earlier 1983 target, and a reduction of the top bracket rate on unearned income was dropped. ${ }^{37}$

Nevertheless, the predominant form of political activity in the legislative stage differs significantly from that of the executive stage. In the earlier stage, hierarchical authority does play an important part-hence the President's refusal to give in to his advisors' pleas for major reformulation. Working a policy initiative through the legislative system, however, involves a confrontation between two systems of power, the executive branch and Congress, each relatively autonomous with respect to the other. The implementation of Reaganomics at the legislative stage would require the practice of three kinds of political skills. The first skill was coping with historic legislative institutional barriers to executive domination. The second skill was the exploitation of opportune circumstances that offer promise of presidential influence in the legislative process. The third skill was the ability to bargain shrewdly in the policy marketplace.

\section{A. Institutional Opposition}

As a general rule, any president must expect some measure of opposition to his policies as an inherent aspect of the constitutional separation of institutions. Thus, the legitimate, legal basis of legislative power, the different electoral base of legislators, the different electoral calendars of Congress, the different perspectives legislators share and different congeries of interests to which their attention is directed all dispose Congress to policy preferences often at odds with the presidential view.

If there is consensus on one point among students of modern congressional politics, it is that on the legislative scale of values, lawmakers' highest priority is the pursuit of the perceived interests of their constituents. In the interest of getting reelected, most legislators attempt to acquire constituent support by devoting their chief efforts to position-taking, credit claiming, and manifesting concern for constituency well-being. ${ }^{88}$ Such

37. See Gregg, Let Us Act Together: Reagan Exhorts Congress, 39 Cong. Q. WEEKLY REP. 331-32 (1981).

38. See M. Fiorina, Congress, Keystone of the Washington Establishment 50-71 (1977); J. Kingdon, Congressmen's Voting Decisions 29-71 (1981); D. Mayhew, Congress: The Electoral CONNECTION 52-77 (1974). 
preoccupations supersede the influence of presidents, lobbyists, sometimes personal convictions, and, if necessary, loyalty to party. ${ }^{\mathbf{3 9}}$

Congress' organization of its work presents another institutional obstacle to executive penetration. A diffusion of power marks the contemporary legislative chambers. Central party dominance of processes and outcomes is a thing of the past. In modern times, Congress is marked by the distribution of expertise, status, and influence among the leaders of semisovereign standing committees exercising near-conclusive jurisdiction over their specialized policy domains. The job of presidential persuasion, therefore, must involve targeting not primarily a leadership figure, but a plurality of influential careerists. In the House of Representatives in 1981, the Reagan Admininstration had to contend with the influence and personal agenda of Ways and Means Committee Chairman Dan Rostenkowski, and in the Senate, with Republican Finance Committee Chairman Robert Dole. The press predictably gave attention to their reactions to the President's legislative presentation speech in February, 1981. Rostenkowski was quoted as stating that the President should be happy to get half of what he was asking and Senator Dole serenely stated his assumption that the tax measure was "going to be modified." 40

The preceding examples suggest only the beginning complexities of legislative maneuvering. Obviously, the interleaved components of Reaganomics engaged the interests and spheres of influence of numerous other committees and subcommittees. In both houses, the appropriations committees (and in the House especially, the many appropriations subcommittees) would have to dispose of the Administration's domestic budget-cutting proposals. Likewise, in both houses the budget committees would play important roles in orchestrating the relationships between revenue, spending, and deficit management within the context of congressional decisionmaking.

Moreover, by 1981, traditional executive-legislative conflict had been reshaped by recent ambitious congressional attempts to assert independence and compete more effectively with executive policy leadership. Thus, the Budget and Impoundment Control Act of 1974 not only placed restraints on the president's authority to impound appropriated funds, but more importantly, created the congressional budgetary process which provided the capability for imposing greater responsibility on legislative policymaking and undergirding that responsibility with the independent source of expertise offered by the Congressional Budget Office. ${ }^{41}$ The spirited growth of congressional staff during the decade of the seventies was yet another indicator of the lawmakers' determination to enhance their competitive

39. See J. Kingdon, supra note 38 , at $\mathbf{1 1 7 - 2 0}$.

40. Gregg, supra note 37 , at 332.

41. See J. Havamenn, Congress and the Budget (1978); A. Schick, Congress and Money: Budgeting, Spending and Taxing (1980); A. Schick, Reconciliation and the Congressional. Budget Process (1981). 
advantages vis-a-vis the executive. ${ }^{42}$ In sum, professional assessments of Congress in the early 1980's characterized the institution as "new" and "resurgent," suggesting notably the institution's increased ability to rebuff presidential dominance. ${ }^{43}$

Finally, that the House of Representatives in 1981 remained controlled by the opposition party constituted yet another obstacle to cooperation between the legislative and executive branches. The normal expectation in such instances of divided government is that the legislative branch will undermine and oppose presidential policies, especially those which run counter to the historic partisan principles of the opposition. Surely, the thrust of Reaganomics seemed to justify the normal expectation. In the case of Reaganomics, however, the normal expectation did not come to pass.

\section{B. Exploiting Opportune Circumstances}

As with most understandings about political and social relationships, principles which are generally accurate and admonitory can be softened by intervening variables in a specific contextual application. Such was the case in 1981 when some of the legislative barriers to presidential agency proved permeable as a result of the interplay of other factors specific to the time. At the outset, the fact that the Senate was under Republican control for the first time in a quarter century was significant. In terms of procedural advantage, Republicans controlled scheduling, staff allocation, committee chairmanships, favored access to the White House, and profited by the incalculable quality of morale enhanced by the recent and unaccustomed electoral triumph. It is true that congressional parties are never monolithic in behavior and that several of the Senate Republican leaders (Dole, Hatfield, Mathias) took positions deviating from the White House line from time to time. Nevertheless, a remarkable exercise of party unity produced the successful adoption of the Economic Recovery Tax Act (ERTA) ${ }^{44}$ in the chamber. Between July 23 and July 29, 1981, some twenty-seven votes were taken in the Senate on amendments offered to the Administration tax package. In only one of those twenty-seven tests was an amendment adopted which ran counter to the leadership's position and split the Republicans badly. In every other instance, crushing majorities of Republicans were responsible for the adoption of favorable amendments or the rejection of hostile amendments. A large number of these votes recorded unanimity among the President's partisans. On only a handful of votes did more than one or two Republicans deviate. On the crucial Finance Committee amendment that assured adoption

42. Congressional committee staff personnnel grew from 1,337 in 1970 to 3,057 in 1979 . $M$. Malbin, Unelected Representatives: Congressional Staff and the Future of Representative Government 253 (1980); see also H. Fox \& S. Hammond, Congressional Staffs: The Invisible Force in American Lawmaking 12-32 (1977).

43. See, e.g., T. Mann \& N. Ornstein, The New Congress (T. Mann \& N. Ornstein eds. 1981 ); 1. Sundquist, The Decline and Resurgence of Congress (1981).

44. Pub. L. No. 97-34, 95 Stat. 172 (1981). 
of the President's package, the Republican vote was fifty-two to one with only Senator Mathias dissenting. ${ }^{45}$

A second factor favoring the Administration's cause in Congress was the instrumental role played by the conservative coalition in the House. Since the 1930's, American legislative issues of significance have led to the mobilization of a coalition in which conservative southern Democrats make common cause with the Republicans. In addition to caucusing and engaging in strategic cooperation, members of the coalition habitually vote together on ideologically freighted issues. ${ }^{46}$ In terms of vote outcomes, the conservative coalition won on a larger number of issues in 1981 than ever in recorded vote analyses. The Congressional Quarterly (CQ), in monitoring roll-call vote behavior, operationally defines a coalition as existing when a majority of Republicans and a majority of Southern Democrats join in opposition to a majority of Democratic party members. This coalition has appeared on about one-fifth to one-quarter of total roll-call votes annually since $C Q$ began monitoring the process twenty years ago. In 1981, the coalition appeared on $21 \%$ of all congressional votes. What is remarkable, however, is that it was victorious (carried the issue) in $92 \%$ of those appearances. ${ }^{47}$ These percentages clearly reflect the temporary condition of an assertively conservative Administration appealing to the supportive instincts of the likeminded in Congress. The evidence of its importance for the adoption of the Economic Recovery plan specifically can be seen in the voting coalition that brought about the adoption of ERTA in the House on July 29, 1981. While the Democrats held a majority of 244 to 191 in the House, the chamber adopted HR 4242, the Administration package, by a vote of 238 to $195 .^{48}$ This vote was the result of the defection of forty-eight Democrats (at the time labelled as "boll weevils") to the Reagan tax measure. Only one Vermont Republican opposed his party's position. Thirty-eight of the forty-eight Democratic defectors were southerners and of the forty-eight, forty also had defected to the Administration budget-cutting cause a month earlier by voting for the Gramm-Latta substitute budget resolution (overturning the House Budget Committee's recommendation). ${ }^{49}$

The campaign for the Reagan economic program in Congress was favored by a third factor in the political environment of 1981-the weakness of the opposition. The Democratic Party in Congress was in disarray. Its presidential leadership, and many of its own liberal leaders had just faced rejection at the polls. The Senate was, of course, controlled by the Republicans. In the House, Speaker Thomas (Tip) O'Neill faced not only the usual problem of conservative deviationists, but even an absence of unity or coherence within the liberal faction. Programmatically, the Democrats

45. Senate Votes, 39 Cong. Q. WeEkly ReP. $1416-19$ (1981).

46. See B. Hinckley, Stability and Change in Congress 205-08 (1983); W. Keefe \& M. Ogul, The American Legislative Process 294-98 (1981).

47. Coalition Vote Study, 41 CoNG. Q. WEEKLy ReP. 2800-01 (1983).

48. See 37 Cong. Q. Almanac 58H (1981).

49. Tax Vote Defectors, 39 CoNG. Q. WeEkLY REP. 1375 (1981). 
seemed unable to offer compelling alternatives to the Reagan construct. To be sure, criticisms of budgetary hard-heartedness and inequity, of contradictions among components of Reaganomics, and of the specter of massive deficits could all be voiced with rationality and conviction. But there was no comprehensive, alternative philosophy to contest Reaganomics. Indeed, early on, the Speaker even surrendered some of his parliamentary discretion by promising to schedule floor votes by midsummer on the Administration's tax and spending programs. An O'Neill aide relayed to journalist Lawrence Barrett the reason for this seemingly naive self-denial:

What the Democrats did, in extraordinary fashion, was to recognize the cataclysmic nature of the 1980 election results. The American public wanted this new President to be given a chance to try out his programs. We weren't going to come across as being obstructionists. ${ }^{50}$

The Democratic leadership's sensitivity to public support for the President suggests another contingent factor helpful to the Administration's cause-in this instance a periodic factor which new chief executives enjoy every four or eight years. This factor is the "honeymoon," a familiar phenomenon. Typically, at least for the first months of a new presidency, the afterglow of electoral triumph and the general goodwill of the citizenry are reflected in a president's highest public opinion ratings. After the honeymoon is over (a variable time, depending on circumstances), presidential popularity normally goes into decline, rarely recovering its early levels. ${ }^{51}$ Consistent with historic experience, the spring and summer months of 1981 saw Reagan riding the crest of his popularity, with periodic Gallup Poll approval ratings hovering around $60 \% .52$ The halo effect of public approbation extends to the media and to Congress even when the president's party does not control the body. Reagan exploited this opportunity, along with others we have noted, in the process of bargaining out the details of implementation of his economic program.

\section{Bargaining and Persuading}

The first and most important strategic decision Reagan made concerned timing and priorities. The reorientation of economic affairs was priority number one. And the assertion of that priority would constitute his first act of policy leadership. Thus, the President established the legislative decision agenda for 1981 in his first two weeks in office. Maintaining the preeminence of $h$ is agenda demanded that competing issues be shunted aside. The chief

50. Interview quoted in L. BARRETT, supra note 27, at 147. A New York Times analysis of polls in June indicated that the Republican Party was attracting the largest number of adherents since 1928, and there was discussion of a possible House takeover in 1982. See N.Y. Times Mag., June 14, 1981, \& 6, at 110-15.

51. See G. Edwards III \& S. Wayne, Presidential Leadership: Politics \& Policymaking 10912 (1985); see also Mueller, Presidential Popularity from Truman to Johnson, 64 AM. PoL. Scr. Rev. 18-34 (1970).

52. On the special Gallup Poll question concerning the President's handling of the economy, from March through August 1981, Reagan's scores ranged up to 60\% approval and never fell below 50\%. Overview of Reagan Approval Measurements, 195 GALLUP REP. 60 (1981). 
contenders for attention within the President's own party were three items usually referred to as social issues. Thus, proposals to amend the Constitution to permit school prayers, to prohibit public funding of abortions, and to prohibit busing for school desegregation were sharply divisive, emotional demands that could not be permitted to overshadow the top priority. ${ }^{53}$ To this end, the cooperation of Senate Majority Leader Howard Baker in controlling the Senate agenda and restraining his extreme right-wing colleagues was crucial, as were the massaging ministrations of the White House legislative liaison operation. The price paid by the President in criticism from the far right was minimal, due largely to his successful assuagement of domestic hawks. As the legislative contest followed its course in the summer months, the Administration would let other issues flag, such as the sale of aircraft to Saudi Arabia, revision of the Clean Air Act, and reinstitution of important provisions of the Voting Rights Act. ${ }^{54}$

A key aspect of the job of presidential persuasion in the legislative process is the creation of indirect pressures on Congress from outside the institution. This pressure takes two basic forms: the mobilization of citizen support through presidential addresses and public appeals delivered at key stages in the process, and the courting of interest group allies in the campaign for legislative leverage. Both the President and his administrative aides performed these functions skillfully and effectively.

Reagan must be given recognition for having personally managed the communications function as well as having executed it. There were three major public appeals in 1981: (1) the general adumbration of Reaganomics in a nationally televised speech from the Oval Office on February 5; (2) formal presentation of the economic package to a joint session of Congress on primetime television on February 18; and (3) a final televised appeal to the nation on July 27, two days before the crucial vote in the House of Representatives. ${ }^{55}$ The February 5 speech was timed for public impact just before a weekend congressional recess when most members would be testing citizen reaction in their constituencies. Substantively, the address was all accommodation and cooperation. The day before the address, competing texts were being debated in the White House and the President, dissatisfied with both, jotted down the main points he wished to make. Significantly, the editing job involved deletion of partisan thrusts at the Democrats and heaping blame for the state of the economy wholly on his predecessors. Rather, the speech was a call for unity and cooperation in greater public interest. The feedback from lawmakers' districts testified to the accuracy of presidential instincts. The February 18 speech showed the stamp of both the President and his top White House aides. Language which criticized the Fed, which articulated the

53. Nathan, The Reagan Presidency in Domestic Affairs, in The Reagan Presidency 50-51 (F. Greenstein ed. 1983).

54. Seizing the Helm, 13 NAT'L J. 1404 (1981).

55. Address to the Nation on Federal Tax Reduction Legislation, Pub. PAPERs 664-68 (July 27, 1981). 
conservative idée fixe of the gold standard, and which echoed technical supplyside dogma in the economic report submitted by George Gilder, was excised. The reaction of Treasury supply-side zealots was disillusionment. Craig Roberts wrote a memo to a Treasury aide lamenting:

I think it is extraordinary that in the first Reagan economic report (even if a minireport), the first explicitly supply-side President ever elected to office provides no explanation whatsoever of the new policy that he is the carrier of and for which he has made so many claims. ${ }^{56}$

While some economic theorists were unhappy, the speech played well before its intended audience. Likewise, the speech of July 27 (when the point of resolution was imminent in Congress) was one part of a broad frontal assault on congressional opponents and waverers. After the speech, congressmen compared the number of constituent communications they had received. The Capitol switchboard load doubled the next day and Western Union mailgrams to the Capitol quadrupled the normal volume. "The bottom line is, the President blew them away," was the verdict of White House Chief of Staff, James Baker. Speaker O'Neill concurred: "We are experiencing a telephone blitz like this nation has never seen. It's had a devastating effect." 57

The natural interest group source of support for the Reagan program was, of course, the business community. The major organizations did indeed deliver for the Administration in the end. Top spokesmen for such groups as the Chamber of Commerce, National Association of Manufacturers, and National Federation of Independent Business suppressed their skepticism about the size of the supply-side tax cut because of the business subsidy elements of the package, notably the accelerated depreciation amendment. There was, at one stage of the bargaining process, some wavering on the part of business groups. ${ }^{58}$ Nonethless, the Carlton Group (signifying the Washington hotel where the business elite would meet, eat, and plan strategy) at length placed its stamp of approval on the "sweetened" package of late July. 59

Ultimately, the Reagan program emerged from the legislative bazaar intact in its essentials after the final challenge of working the system had been met: direct, head-to-head bargaining between President and legislators. To appreciate the nature of the bargains struck and the appropriateness of strategies and tactics involved, one must consider some of the detailed elements of the package as it made its way through the process. Such an analysis is provided in the next section.

56. P. RoBerts, supra note 30, at 103.

57. Wehr, White House Lobbying Apparatus Produces Impressive Tax Vote Victory, 39 Cong. Q WeEkLY REP. 1372 (1981).

58. See infra text accompanying notes 68-69.

59. Keller, Democrats and Republicans Try to Outbid Each Other in Cutting Taxes for Business, 39 Conc. Q WeEKLY REP. 1133 (1981). 
D. Synopsis

(1) The initial February proposal called for a "clean bill"-one which enacted two major principles, personal tax reductions of $10 \%$ each year for three consecutive years and, second, a major business tax reduction which greatly shortened the depreciation period during which companies could claim tax credits for such costs as buildings, vehicles, and equipment. ${ }^{60}$

(2) The main response during the April-May deliberations in the House was the Rostenkowski (House Ways and Means Committee) counter of a oneyear tax cut and, as a strategy to court boll weevils, a "conservative" proposal to cut the top marginal tax bracket rate on unearned income from $70 \%$ to $50 \% .61$

(3) June brought a standoff between Reagan and Rostenkowski on the personal tax cut, the President holding firm to the three-year principle. The President was pleased to accept a reduction from $70 \%$ to $50 \%$ in the top marginal tax bracket, something he had originally sought anyway. ${ }^{62}$

(4) With an early arrangement with Rostenkowski unattainable, the Administration gave its support to a "bipartisan" Hance-Connable substitute for the Ways and Means bill. (Kent Hance was a conservative Democrat from Texas and his colleague, Barber Connable, was the ranking Republican on the House Ways and Means Committee.) The substitute produced a $5 \%, 10 \%$, $10 \%$, thirty-three-month personal tax cut, a somewhat reduced depreciation write-off subsidy, and a laundry list of special interest tax benefits to various competing groups perennially lined up at the revenue trough. ${ }^{63}$

(5) A bidding war between Democrats and Republicans over specific benefit offers to particular interests and a return to a more hospitable business depreciation subsidy constituted the major developments in the final stage. When the House adopted the Hance-Connable substitute for its "own" Ways and Means Committee version, the Administration forces had won the bidding war. ${ }^{64}$

What remains is to identify the nature of the negotiating activities and their orchestration in this exercise. A good starting point is the idea of work itself in the literal sense. Successful policy bargaining requires persistent, lengthy, patient, and determined devotion to the job at hand. Reagan demonstrated his willingness and ability personally to struggle to the end. The strategically timed speeches, the now legendary telephone calls, the White House dinners, photo opportunities, and the boundless promises of favors are testimonials to the old and new fashioned lobbying skills practiced in 1981.65 In the course of the campaign, the President may well have gained

60. H.R. 4260, 97th Cong., 1st Sess. (1981).

61. Fessler, House Floor Battle Looming on Tax Cut Bill, 39 Cong. Q. WeEkLY ReP. 1323, 1324 (1981).

62. Id. at 1323-24.

63. H.R. 3849, 97th Cong., lst Sess. (1981).

64. H.R. 4242, 97th Cong., lst Sess., 127 Cong. REc. H4898-4905 (daily ed. July 24, 1981); see also 127 Cong. Rec. H5992 (daily ed. Aug. 4, 1981).

65 . Wehr, supra note 57 , at $1372-73$. 
significant support by proffering amendments to aid the constituencies of individual members (such as the $\$ 2500$ tax credit to holders of gas and oil royalties) and by making promises not to campaign against Democrats who supported the economic program.66 The President did not rely on favors alone, however. In June, the President threatened to use his constitutional authority to force Congress to stay in session in August if work on the tax program was incomplete-a threat that could not be dismissed as empty, given the President's standing in the opinion polls at the time. ${ }^{67}$

The determination of the President not to give in on the three-year tax cut principle-seen as stubbornness by some in his own Administrationsuggests his own sense of bargaining advantage. In addition, skillful analysis by his White House legislative apparatus was helpful. Lawrence Barrett cites evidence of the analytical quality of the Legislative Study Group's intelligence in a June memorandum to the President which probed Chairman Rostenkowski's personal and political motives:

Some think that he would like to have compromised last week, but that he simply could not control the left side of his committee. He is in a difficult situation. He now runs the risk of being "rolled" in his first time out as chairman of Ways and Means (and with his eye on the Speakership). On the other hand, by not compromising with us he preserves his position with O'Neill and with the liberal wing of the Democratic Party. And if-as they think likely-our economic policies fail, they could become the ultimate winners. ${ }^{68}$

The President and his forces can be charged with only one major miscalculation at a significant juncture in the bargaining process. As the pitch of bargaining heightened, the President made a gesture to those who feared the deficit costs of his program. In a June 4 compromise, the Administration announced support for reductions in the business depletion write-off benefits. Since these had been the primary inducement to business to suppress its skepticism about Kemp-Roth and support the President, the fraternity now felt betrayed. The Rostenkowski forces seized the opportunity by bidding for business support of the Ways and Means version by offering new gratuities. And for a brief time, business did indeed dally with unaccustomed legislative patrons. Within days, however, the Administration recouped by promising, in private meetings with lobbyists, the restoration of depreciation advantages. In a week the business elite renewed support of the Reagan package. One lobbyist thought that perhaps organized business should have let the President dangle a bit longer:

I think all the groups came back on board much too quickly. There was more to gain

[by waiting]. But it's awfully difficult to turn down the personal lobbying of the

President of the United States, especially when their hearts are with him anyway. ${ }^{69}$

The preceding events constitute an example of how Reagan, in working his initiative through the legislative system, permitted elements of ideology to

66. Keller, supra note 59 , at 1133,1136 .

67. Wehr, Reagan May Try to Block August Recess If Work Unfinished on Tax Cut Measure, 39 Cong. Q. WEEKLY REP. $1134-35$ (1981).

68. L. BARRETT, supra note 27, at 167-68.

69. Keller, supra note 59, at 1136. 
give way to pragmatic strategy. Clearly, the largest concession the President made was in permitting his pristine clean bill to become a vehicle for meeting the demands of a host of special interests with a grab-bag of (sometimes inconsistent) tax benefits. Although possessing inbred convictions about the proper direction of social, economic, and political change, Reagan was not immobilized by ideological rigidity and recognized that the calculus of means and ends dictated that concessions be made.

\section{IV}

\section{Policy Arenas and Presidential Agency}

Examination of public policy processes by students of government traditionally considers the stages of the process, institutional perspectives and interactions, and the forms in which power and influence are distributed and exercised. The foregoing pages have exemplified that orientation. There is another twist to the analytic kaleidescope, however, which may serve to rearrange the explanatory pieces into a new configuration explaining partially the consummation of the Reagan revolution. The new unit of analysis is defined as the type of public policy under investigation. For at least two decades, political scientists have examined arenas of domestic policy which are constructed by looking at the impact of the policy on society and at the relationships among the participant policy actors. Although there have been elaborations and refinements of the originally proposed types, the three major arenas continue to be provocative of research and further theorizing. These are the distributive, the regulatory, and the redistributive types. ${ }^{70}$ The first two policy types will be characterized briefly, the third in more depth.

Much of the activity of modern American government involves the distribution of value to individuals and groups. These benefits typically take the form of money, but may include services, and even occasionally status. The benefits are distributed individually to groups of supplicants without any explicit relationship among them. Typically, they are not perceived, at least in the short run, as being granted to some at the expense of others. Examples range from public works projects, agricultural subsidies, and mortgage insurance loans, to grants to localities for hospital construction, educational aid, or scientific research support. These policies are so pervasive, so routinely enacted and reenacted, and so widely sought that they tend to be activities of low public salience and low controversy. A large proportion of the body of distributive policies is processed by stable subsystems of political actors composed of high level bureaucrats, congressional committee leaders, and interest group operatives. These mutually accommodating political subsets are sometimes referred to as the "iron triangle." The phenomenon of

70. This influential policy typology was originally proposed by Professor Theodore Lowi of Cornell University in 1964. See Lowi, American Business, Public Policy, Case Studies, and Political Theory, 16 World Pol. 690-91 (1964); Lowi, Four Systems of Policy, Politics and Choice, 32 PUB. Ad. Rev. 298-310 (1972). An example of a widely read application and elaboration is R. RIPLEY \& G. FrankLIN, Congress, The Bureaucracy and Public Policy (1980). 
distributive politics is an outgrowth of the emergence of the positive, social service state, the growth of bureaucracy, and the potency of modern interest group activity.

The other face of the modern state looks in the direction of restraint rather than beneficence. Thus, regulatory policies are characterized by state limitations placed upon the discretion of individuals and groups. The regulatory hand of the modern American state extends far beyond legal restraints on types of criminal activity to limitations on business behavior, the lending of money, the provision of transportation, the emission of pollutants, and thousands of other private and commercial activities of citizens. Winners and losers are more prominent in the regulatory arena and thus bargaining over the achievement of or avoidance of a new state restraint is less routine, more conflict laden, more politically salient, and engages the participation of more high-level political actors than does the distributive environment.

On a scale of controversy, redistributive policies attract the sharpest conflict and are the most difficult to enact. This is because they are perceived as overtly benefiting one group in society at the expense of others. Fundamental reallocations are seen as taking place. Established relationships in income, class, status, and even rights are challenged in the redistributive arena. Thus, an antipoverty program which seeks to uplift the status of the poor (at a cost to the middle class), a voting rights act which seeks to secure the political rights of one sector of the society at high potential cost to a previously advantaged sector (with a monopoly of political power), or the enactment of a tax measure which is seen as having the consequence of redistributing income, are all examples of policies fraught with political passion.

With the last example, we have conjured the stage on which the Reagan revolution was played out. Since redistributive issues involve reallocation of fundamental values, they are inevitably couched in ideological terms of debate between two polar opposites-liberal-conservative, rich-poor, we-they. As such, they achieve high political prominence. For a time, pragmatic, accommodationist American politics becomes starkly partisan and divisive. Salience is high. Attention is paid. Peak political actors are engaged. Andof greatest significance in the rhythms of American politics-overt presidential initiative and persistent presidential support characterize the great import and high drama of redistributive issues.

And how is the great conflict which accompanies such confrontational positions resolved? In democratic politics, rarely does one side or the other achieve total victory. Frequently, a temporary, partly symbolic conquest is achieved and then slowly disaggregated and dissipated by subsequent political revisions which often have the character of distributive politics. For example, the Johnson war on poverty was apparently won in 1964 with the Economic Opportunity Act. ${ }^{71}$ In the years that followed, concessions to strident

71. Pub. L. No. 88-452, 78 Stat. 508 (1964). 
opposition groups and local political establishments came more and more to resemble the traditional ethic of distributive payoff. ${ }^{72}$

In the instance of the Reagan economic program, a fundamentally redistributive program was established by making concessions to distributive imperatives in the very process of legislative implementation. The resolution of a redistributive conflict was achieved by side-payments to a sufficient number of claimants of the distributive largess of government. Put simply, the demands of thrift institutions for tax exempt savings certificates, of high technology industries for tax credits to stimulate research, of farmers for inheritance tax relief, of international firms for tax reduction for overseas workers, and of distressed industries (the automobile and railroad industries, for example) for investment tax credits-each of these and dozens more were met in distributionist concessions to resolve the basic conflict over the redistributive thrust of the core economic program. ${ }^{73}$ Professors Ripley and Franklin arrived at a general theoretical conclusion about the redistributive policy process which is here confirmed:

The attainment of redistributive policy is achieved at a cost of diluting its impact by adding or emphasizing distributive elements. Programs that are purely redistributive are virtually impossible to enact. Programs that have distributive elements broaden the base of support and both camouflage and reduce the redistributive elements. ${ }^{74}$

The true nature of the redistributive quality, and thus the core revolutionary impact of the Reagan economic program, needs to be specified sharply. In the short run, redistribution of fiscal rewards in class terms is apparent. The first major examination of the consequences of Reaganomics published by the Urban Institute in 1982 concluded that Administration programs

provide modest income gains (after taxes and transfers) for the average household. However, the gains to families in the upper income brackets are quite large and, on average, low income families will experience a small net loss. . . . It is clear that the changes introduced thus far make the distribution of incomes less equal and require some sacrifices by low-income families. ${ }^{75}$

More recently, a Congressional Budget Office study reached the same conclusion, calculating that the tax and spending programs result in a net income loss of $\$ 390$ to households with incomes under $\$ 10,000$ and a net income gain of $\$ 8,270$ to households with incomes of $\$ 80,000$ and more. ${ }^{76}$

The greater potential, long-term redistributive effect of Reaganomics, however, is more fundamentally systemic. That is, the premise of the Reagan world view is a belief in reallocation of governmental functions. This means less direct social service activity (program cuts), less interference with free market forces (deregulation), and more public encouragement to economic

72. R. RIPLEY \& G. FrankLin, supra note 70, at 172-74.

73. See the extended catalogue of ERTA's tax subsidy provisions in Keller, supra note 59, at 1132-33. See also Samuelson, For the Economy, Unanswered Questions, 19 NAT'L J. 1405-10 (1981).

74. R. Ripley \& G. Franklin, supra note 70, at 201-02.

75. J. Palmer \& I. Sawhill, The Reagan Experiment-An Examination of Economic and Soclal Policies under the Reagan administration 383 (1982).

76. N.Y. Times, April 4, 1984, \& A, at 17, cols. 4-6. 
enterprise. To the extent that total government revenue shrinks severely (which of course has happened), the seeds are planted for a long-term slowdown in the growth of domestic support programs.

A final question asks how redistributive policies come about. One answer, which points to presidential agency, has already been suggested. Since modern presidents have come to be recognized as leaders and managers of the national public policy process, their initiatives are crucial. Yet redistributive initiatives are the most difficult of all domestic acts. For policy ambitions of this sort to succeed, the broader political environment must be permissive. Two kinds of observations may help to account for the facilitative political climate of 1981 .

The first of these looks to the presidency itself. Professor James David Barber has analyzed the impact of the forces of presidential character on the conduct of the office and the choices among policies. He has also recognized that

Presidential character resonates with the political situation the President faces. It adapts him as he tries to adapt it. . . . Besides the power mix in Washington, the President has to deal with a national climate of expectations, the predominant needs thrust up to him by the people. ${ }^{77}$

It is that "climate of expectations" which seems significant at this point. Professor John Kingdon, in a perceptive study of policies and their agendas, has observed the phenomenon of a "national mood," which politicians sense is an important conditioner of choice as well as an augury of success.

A shift in climate, according to people who are actively involved in making or affecting public policy, makes some proposals viable that would not have been viable before, and renders other proposals simply dead in the water. ${ }^{78}$

Such a shift in climate and national mood had taken place by the opening of the ninth decade of the century, and Ronald Reagan resonated with this climate of expectations. The national mood was neither philosophically motivated nor programmatically articulated. More than anything else the mood was one of uncertainty mixed with disillusionment at the record of its government in coping with the big problems in recent years. Reagan, a figure out of the past, preaching the old-time religion, provided a political alternative and his ideas, an opportunity for testing once again. It would not be the first time in the American political experience that a dynamic presence wedded to unconventional ideas had attracted the tentative support of the voters.

The shift in mood, however, involved something more than diffuse, uncertain longings for the promise of leadership-though that was important. And this is central to the explanation of the early tolerance of Reaganomics. A journalist assessing the Reagan tax victory of July, 1981, concluded that the major explanation of success was that the President had won the rhetorical argument. Speaker O'Neill and Chairman Rostenkowski billed the

77. J. BARBER, supra note 13 , at 8-9.

78. J. KINGDON, supra note 20, at 156 . 
Democratic tax package as one which would benefit working Americans and castigated the Reagan program as one of plutocratic "trickle-down" inequities. Reagan, on the other hand, argued the equity of his program as holding out tax relief to all brackets, from the highest to the lowest. The public response in the summer of 1981 would suggest that Americans were prepared to tolerate the Reagan prescription. ${ }^{79}$

There is some independent evidence that traditional, egalitarian liberalism did not claim the support of most Americans by the 1980's, and that "soak the rich" proposals were viewed with skepticism. Public opinion specialist, Daniel Yankelovich, in analyzing a variety of poll data including his own, had concluded that many Americans expressed themselves in favor of programs to "level-up" but opposed notions which promised "levelling down." He found, for example, two-to-one majorities in support of reducing the capital gains tax. His general conclusion would be chilling to the President's policy opponents:

But whatever the reason, the majority of Americans do not want any redistribution that can be interpreted as taking away from the successful fruits of what they have earned. The national psychology holds that those who play the game according to the rules (and the rules include luck, hard work, and "good connections") are entitled to their success, and should be able to reinvest liberally what they get. ${ }^{80}$

The verdict must be that in 1981 Ronald Reagan was able to make a revolution because he could count, if only temporarily, on the tolerance of a middle class polity that was apparently prepared to engage with him in what Lawrence Barrett has described as "Gambling With History." 81

\section{V}

\section{Afterword: Counter-Revolution OR Thermidor?}

Even as the President was enjoying the fruits of his legislative victory, the deepening recession made the gambles seem more treacherous. The tax cuts turned out to be greater than expected. (Because of lower inflation, tax bracket "creep" was slowed and the value of the depreciation deduction was enhanced.) Spending increased in costly entitlement commitments as the recession threw more people on government resources. By the summer of 1982 , the deficit projections which had been a haunting specter to the President's advisors a year earlier, were now underestimated realities.

The President was persuaded to take a step back in his conservative policy crusade. On August 19, 1982, Congress passed, with Administration support, the Tax Equity and Fiscal Responsibility Act (TEFRA) ${ }^{82}$ which mandated a $\$ 98.3$ billion tax increase. The sources of these new revenues consisted of a host of excise tax hikes, "corrections" of certain 1981 business gratuities which had summoned higher inflation (such as the depreciation write-offs),

79. Kirchsten, Medium and Message, 13 NaT'L J. 1427 (1981).

80. D. Yankelovich, New Rules 141 (1981).

81. L. BARRETT, supra note 27.

82. Pub. L. No. 97-248, 96 Stat. 324 (1982). 
and withdrawals or reductions in many of the special distributive benefits for business legislated in $1981 .{ }^{83}$

Clearly, there were elements of reversal in the new measure. Hard-line supply-side ideologues were devastated. Jack Kemp fought the President in Congress. Former Treasury aide Craig Roberts characterizes TEFRA as "the unravelling of Reaganomics." 84 The President's men billed the tax measure as "fine-tuning," rather than as a significant departure from economic principles. The real extent of the change probably rests somewhere between these extremes. As Heclo and Penner have judged:

While some accuse him [Reagan] of doing a policy flip-flop, this is an exaggeration. The tax bill is too important to be called a fine-tuning of his overall fiscal policy, but it only offsets a relatively small portion of the 1981 tax cut and leaves in place a more than 5 percent cut in overall tax burdens relative to GNP between fiscal 1982 and fiscal 1983.85

One indication of abiding elements of the philosophy of the Reagan program in TEFRA is that the measure also contained the legislative concession of spending reductions amounting to $\$ 17.5$ billion in domestic programs. Such cuts were concentrated in health programs, limits on medicare payments to hospitals, and the like. ${ }^{86}$

In sum, if we may borrow a metaphor from the historians of more violent revolutions and apply it to the innovations of 1981 , it might be said that a Thermidorean reaction had set in. That stage of convalescence following revolution has frequently been observed and involves elements of restoration, consolidation, and the softening of sharp edges. The historian, Crane Brinton, has averred: "In some sense the phenomenon of reaction and restoration seems almost inevitably a part of the process of revolution." 87 Whether indeed the events discussed in this essay constitute a historic turning point in political-economic relationships or a massive aberration, only future generations will be able to judge finally.

83. For an analysis of the provisions of the act, see Tate, Wehr \& Sarasohn, Congress Clears $\$ 98.3$ Billion Tax Increase, 40 Conc. Q. WEEKLY REP. 2035-46 (1982).

84. P. Roberts, supra note 30, at 226-45.

85. Heclo \& Penner, Fiscal and Political Strategy in the Reagan Administration, in THE REAGAN Presidency 35 (F. Greenstein ed. 1983).

86. Tate, Wehr \& Sarasohn, supra note 83, at 2035.

87. C. Brinton, The Anatomy of Revolution 263 (1952). 